\title{
Paideusis
}

\section{The Case for Philosophical Mindedness}

\section{Theodore Michael Christou and Shawn Michael Bullock}

Volume 20, Number 1, 2012

URI: https://id.erudit.org/iderudit/1071840ar

DOI: https://doi.org/10.7202/1071840ar

See table of contents

Publisher(s)

Canadian Philosophy of Education Society

ISSN

0838-4517 (print)

1916-0348 (digital)

Explore this journal

Cite this article

Christou, T. \& Bullock, S. (2012). The Case for Philosophical Mindedness.

Paideusis, 20(1), 14-23. https://doi.org/10.7202/1071840ar
Article abstract

This essay is an extended argument for a philosophical disposition with regards to pedagogy, and an argument for all educationists, not merely a select few toiling in the academy, to seek wisdom. Engaged in vocations involving teaching and learning, we must aspire to be wise. Being a philosophically minded educationist means occupying a radical middle between opposing viewpoints and thinking critically, in action, about educational experiences. Far from stereotypical notions linking philosophy to abstract ideals of the ivory tower, we argue that being an educationist and taking this responsibility seriously means being a frontline classical philosopher-one who loves wisdom and who is willing to facilitate the birth of ideas. (c) Theodore Michael Christou, Shawn Michael Bullock, 2012

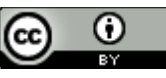

This document is protected by copyright law. Use of the services of Érudit (including reproduction) is subject to its terms and conditions, which can be viewed online.

https://apropos.erudit.org/en/users/policy-on-use/ 


\title{
The Case for Philosophical Mindedness
}

\author{
THEODORE MICHAEL CHRISTOU AND SHAWN MICHAEL BULLOCK \\ Queen's University and University of Ontario Institute of Technology
}

\begin{abstract}
This essay is an extended argument for a philosophical disposition with regards to pedagogy, and an argument for all educationists, not merely a select few toiling in the academy, to seek wisdom. Engaged in vocations involving teaching and learning, we must aspire to be wise. Being a philosophically minded educationist means occupying a radical middle between opposing viewpoints and thinking critically, in action, about educational experiences. Far from stereotypical notions linking philosophy to abstract ideals of the ivory tower, we argue that being an educationist and taking this responsibility seriously means being a frontline classical philosopher - one who loves wisdom and who is willing to facilitate the birth of ideas.
\end{abstract}

Our thesis is that educationists are philosophers and should take that responsibility seriously. By implicating educationists as opposed to educators or pedagogues, this argument attends broadly to stakeholders in education-including students, teachers, parents, administrators, departments of education, and social organizations - and entreats each to approach teaching and learning contexts as philosophers should. Philosophy concerns matters of ethics, reason, affect, argument, and language. Philosophers are by classical definition lovers and nurturers of wisdom. The purpose of this essay is to persuade educationists to be philosophically minded.

Philosophical mindedness is operatively defined as an ethic, or habit of mind, imbuing educational action and reflection with an awareness of the philosophical implications and concerns of teaching and learning. This essay is an extended argument for the assumption of a philosophical disposition with regards to pedagogy, and an argument for all educationists, not merely a select few toiling in the academy, to seek wisdom. Engaged in vocations involving teaching and learning, we must aspire to be wise.

The idea of being philosophical might well bring to mind notions of retreating from the active life into a contemplative pose. After teaching and learning, one withdraws to a space of reflection or, alternatively and perhaps concurrently, one reflects and then engages in the acts of teaching and learning. In various ways, philosophizing and teaching, as verbs, can be interpreted as occupying separate spheres of activity. According to this traditional viewpoint, these spheres might border or overlap, but they are distinct.

A philosophically minded educationist, by contrast, depicts theory and practice as being densely interwoven. By rejecting traditional suppositions, philosophical mindedness occupies a "radical middle" between narrowly delimited and ultimately misleading characterizations of theoretical or practical approaches to teaching and learning. ${ }^{1}$ In lived experience, we would argue that there is little separation

\footnotetext{
${ }^{1}$ Shawn M. Bullock and Theodore Christou, "Exploring the Radical Middle Between Theory and Practice: A Collaborative Self-study of Beginning Teacher Educators," Studying Teacher Education: A Journal of Self-study of Teacher Education Practice 5, no. 1 (2009): 75-88. Bullock and Christou define the notion of a radical middle as

(C) Copyright 2012. The authors, Theodore Michael Christou and Shawn Michael Bullock, assign to Paideusis the right of first publication and educational and non-profit institutions a non-exclusive license to use this document for personal use and in courses of instruction provided that the article is used in full and this copyright statement is reproduced. Any other usage is probibited without the express permission of the author.
} 
between thought and action. This position follows from John Dewey's articulated position on the inherent unity of life and the importance of assuming a pragmatic philosophic approach. Dewey argued before the New York Academy of Medicine on November 17, 1927 that pragmatism is "discontented with the current separation of theory and practice, knowledge and action, regards thought and beliefs which proceed from it as themselves modes of action and strives to envisage them in their directive office of conduct."'2

From the pragmatic approach, philosophy is better understood as a critical disposition to the world, rather than a strict adherence to a school of abstract theorizing. Dewey's teaching syllabus at Columbia University, concerning the applications of pragmatism as a philosophical orientation, expressed this approach most cogently: "Philosophy as method instead of as doctrine." 3 This, he believed, prompted "change in the individual with the transition from custom to reflection as method of action." 4 Critical reflection and philosophy in action are at the very core of what is here described as philosophical mindedness in education.

\section{Philosophy in Action}

Philosophy depicted as an ongoing, active, and querying disposition to life is certainly not new, particularly with respect to issues of teaching and learning. The model of Greek philosophy presented to us through the dialectics of Plato demonstrated a philosophical disposition entailing active, social, and educative contexts. Exploring philosophical questions in the form of dialogue was not exclusive to Plato, as a number of Socrates' students adopted the form. It was, as Harold Tarrant explains, "a natural form for these writers to adopt. They wanted to depict Socrates in action." 5 Seizing upon the Socratic paradigm of philosophy as a way of life, and inviting an ongoing inquiry into the meanings and activities of that life, philosophical mindedness in education calls for a return to the classical roots of philosophia, the call to wisdom.

Pierre Hadot, appealing to Aristotle, explained that philosophy as reflective, self-aware activity must be framed in terms of its nascent period in the ancient world in order to be understood for what it was-primarily, a way of life. ${ }^{6}$ Hadot believed that,

ancient philosophy proposed to mankind an art of living. By contrast, modern philosophy appears above all as the construction of a technical jargon reserved for specialists. ${ }^{7}$

follows: "a productive way of thinking about the relationship between theory and practice; radical in the sense of being contrary to the pervasive assumptions of thinking about teacher education in terms of theory-into-practice, middle from recognition of our experience that theory and practice are embedded in, and necessarily inform, each other" (p. 75).

2 John Dewey, "Body and Mind" in The Later Works of John Dewey, 1925-1953, Volume 3: 1927-1928 (Carbondale, IL: Southern Illinois University Press, 2008), 25.

3 John Dewey, "Syllabus: The Pragmatic Movement of Contemporary Thought", in The Middle Works of John Dewey, 1899-1924, Volume 4: 1907-1909 (Carbondale, IL: Southern Illinois University Press, 2008), 257.

${ }^{4}$ Dewey, "Syllabus," 255.

${ }^{5}$ Harold Tarrant, introduction to Plato: The Last Days of Socrates trans. Hugh Tredennick and Harold Tarrant (Harmondsworth: Penguin Books, 1993), xi.

6 Pierre Hadot, What is Ancient Philosophy? (Cambridge, MA: The Belknap Press, 2002). Hadot cites Aristotle's Politics 1, 2, 1252a24: "Our goal, then, is to seize this phenomenon at its origin, remaining quite aware that philosophy is a historical phenomenon which arose at a particular point in time and has evolved up to the present."

${ }^{7}$ Pierre Hadot, Philosophy as a Way of Life (Cambridge, MA: Blackwell Publishers Inc., 1995), 272. 
Robert Warden, likewise, considering the history of philosophy, anchors philosophic activity in the agonistic context of classical Athens where "doing and living" philosophy constituted an "entire and vibrant tradition." Within such a tradition, philosophy, as an orientation to life, "is no longer a theory divided into parts, but a unitary act, which consists in living logic, physics, and ethics. ... We no longer theorize about moral action, we act in a correct and just way."' Ultimately, with regards to matters of pedagogy and education, the appeal to philosophical mindedness is a call for all educationists to collaboratively debate, explore, scrutinize, and enact a just and correct education.

In discussing the broader and overarching aims of philosophical mindedness, it is prudent at this point to unpack one half of that term, mindedness. Yoked to philosophical activity and depicted as a vital aim for educationists, it becomes a novel articulation. This entails a movement from discourse about philosophy to philosophy itself, a distinction made explicitly in the Stoic tradition. ${ }^{10}$ Hadot defines "philosophy itself" as "the philosophical way of life . . . no longer a theory divided into parts, but a unitary act, which consists in living logic, physics, and ethics." 11 Being philosophically minded, in other words, hinges on educationists conceptualizing philosophy as a way of being rather than as a body of discourse, or as a body of knowledge.

We can consider the parallel case of history education, which is undergoing a shift similar to the one we propose for philosophy of education. There have been three significant developments, spanning nearly a century, yet the prevailing notions of history as content or discourse are being supplanted by the understanding that history is a habit of inquiring about and a way of acting upon the world. A brief outline of historical mindedness as an aim in history education, will demonstrate how philosophy, like its humanistic counterpoint, must best be appreciated as a way of being.

At the dawn of the nineteenth century, the American Historical Society formed a Committee of Seven to report on the study of history in schools. ${ }^{12}$ In its discussion of the "Value of Historical Study," the Committee recommended that attention be given to the cultivation of present- and historicalmindedness, which were habits conducive to a critical awareness of contemporary life and the past. ${ }^{13}$ Notable was the depiction of history in education in terms of dispositions and outlooks rather than skills or merely content. These dispositions included a detachment from immediate pressures, a willingness to search for comparisons and analogies, a readiness to subject emotions to reason, consideration of multiple perspectives in issues, and weighing the forces of continuity and change. ${ }^{14}$ The concept of mindedness is used in appealing to habits of mind and human life as opposed to retention of data or dexterity with particular skills.

During his review of two texts on the subject of history education for the Canadian Historical Review a century later, Ken Osborne reintroduced the notion of historical-mindedness, describing it as "a valuable, indeed indispensable, attribute of democratic citizenship." 15 Osborne called on budding research in history to attend not only to the thoughts, habits, and morsels of knowledge that mature in studying the past, but to consider how history affects actions, worldviews, and the meanings of being

\footnotetext{
${ }^{8}$ Robert Wardy, Doing Greek Philosophy (London and New York: Routledge, 2006), 19-20.

${ }^{9}$ Hadot, Philosophy as a Way of Life, 267.

10 See, for example, Diogenes Laertius, Lives of the Philosophers, trans C. D. Yonge (London: Bohn's Classical Library, 1895), Book 7, Section 39, http://www.attalus.org/old/diogenes7b.html.

${ }^{11}$ Hadot, Philosophy as a Way of Life, 267.

12 Andrew C. McLaughlin et al., "The Study of History in Schools: A Report to the American Historical Association by the Committee of Seven, 1898" (American Historical Association, 1898), ,http://www.historians.org/pubs/archives/CommitteeofSeven/index.cfm

${ }^{13}$ McLaughlin et al., "The Study of History in Schools . . ."

http://www.historians.org/pubs/archives/CommitteeofSeven/ReportValue.cfm

${ }^{14}$ McLaughlin et al., "The Study of History in Schools ..."

15 Ken Osborne, "Book Reviews_Knowing, teaching and learning history, ed. Peter Stearns, Peter Seixas, and Sam Weinburg (New York: New York University Press, 2000), and 'L'histoire à l' école: Matière à penser,' Robert Martineau (Paris and Montreal: L'Harmattan, 1999)," The Canadian Historical Review 82, no. 3 (2001): 548-604.
} 
human. It is in reflecting this last point that the potential for philosophical mindedness to constitute a way of considering the entire enterprise of education in the context of human life, values, and norms gains force.

In reformulating the notion of historical mindedness as an educational aim, Rosa Bruno-Jofré and Karen Steiner were concerned with the promotion and establishment of an "ethically defensible vision of education." 16 The development of historical understanding was depicted as a path toward the construction of a literate and critically minded citizenry. Philosophy, because it envelops rational, normative, affective, and linguistic concerns-domains that are, equally, the concerns of education-is a vital and eminently practical tool for educationists. Philosophical mindedness for educationists requires, at the very least, an understanding of the implications of our actions, discourse, and ideas within various and overlapping spheres of educational activity. At its best, it demands an ongoing, heroic scrutinizing of our personal, institutional, and collective pedagogical beliefs.

\section{Always the Midwife}

When educationists lay out firm principles, perhaps using the rhetoric of best practices or behavioural objectives, certain presumptions are taken regarding what is certainly correct and good. This presumptuousness may take the form of a canon or curriculum that each student must pursue with the expert guidance of a teacher. North American bestsellers in education, such as Eric Donald Hirsch Jr.'s Cultural Literacy: What Every American Needs to Know proffer one instance of educational thinking leading to arguments on the essential nature of certain knowledge. ${ }^{17}$ In the Canadian context, Jack Granatstein's Who Killed Canadian History?, accused social studies and history courses across the country of failing to teach the essential aspects of Canada's past, sparking a flurry of discussion and debate in the media and in the academy. ${ }^{18}$

Alternatively, presumptions of certainty in education premised on evidence-based research may lead to the construction of frameworks to guide policy on teacher education or school funding; Linda Darling-Hammond and Joan Baratz-Snowden's influential work, A Good Teacher in Every Classroom: Preparing the Highly Qualified Teachers our Children Deserve, offers models for understanding what teachers need to do and what they need to know to be most effective. ${ }^{19}$ The question at the heart of this problematization lies not with the research methods, evidence bases, or cultural traditions informing presumptions but with the entrenchment of presumptions as truths. Neither should it be stated that presumptions and assertions should not be made. All educational pronouncements and statements, however, should be seen as provisionally and tentatively claimed as opposed to certain.

Cautious with his claims to truth, Socrates (as Plato depicts him in the dialogues) appeals to questions as a means of probing the certainty of his interlocutors. The philosopher is always en garde, engaging in dialogues like fencing matches leading inexhaustibly towards an active construction of deeper and richer understanding. Socrates' questions stabbed at presumptions of knowledge; the stings he launched forced others to defend their claims to truth or understanding, or to reformulate these in other terms and along other lines. ${ }^{20}$ What is at stake for the philosopher is a life lived poorly, premised

\footnotetext{
16 Rosa Bruno-Jofré and Karen Steiner, "Fostering Educative Experiences in Virtual High School History," Encounters on Education 8 (2007): 69.

${ }^{17}$ Eric D. Hirsch Jr., Cultural Literacy: What Every American Needs to Know (New York: Random House Inc., 1988). ${ }^{18}$ Jack L. Granatstein, Who Killed Canadian History? (Toronto: HarperCollins, 1998).

${ }_{19}$ Linda Darling-Hammond and Joan Baratz-Snowden, eds. A Good Teacher in Every Classroom: Preparing the Highly Qualified Teachers our Children Deserve (San Francisco: Jossey-Bass, 2005).

${ }^{20}$ In defense of his teaching methods during his trial for corrupting the youth and teaching false gods, Socrates referred to himself as Athens' gadfly. His mission, which was divinely inspired, was to prod the Athenians to examine their beliefs with the ultimate aim of fostering humility with regards to knowledge claims and wisdom.
} 
on false assumptions, and leading away from virtue. Being philosophically minded, as Socrates compels his fellow Athenians to be via question and dialogue, is a means by which we educationists pursue educational aims tentatively and cautiously, at the risk of presuming knowledge of things uncertain. ${ }^{21}$

As a model of being philosophically minded, Socrates relentlessly pursues richer and deeper understanding, arguing that a life that is not examined continuously is not worth living. ${ }^{22}$ As educationists, committed to a life concerned with teaching and learning, knowledge and understanding, action and contemplation, we must not rest on our presumptions. Research, policy, curriculum, and tradition must be scrutinized, not immortalized. Accordingly, an active and ongoing disposition towards the interrogation of knowledge claims puts the philosopher in a precarious position; it is difficult, perhaps even strenuous, to be philosophically minded. We return to this matter in the discussion of philosophical mindedness as an ethic, which follows below.

The psychological construct of cognitive dissonance sheds some light on the human challenges to philosophical mindedness. In Tavris and Aronson's Mistakes Were Made (But not by Me), the authors make the argument that we take steps to avoid a state of cognitive dissonance at all costs. Thus, when faced with a proposition that is not in accord with our prior assumptions and beliefs, our initial reaction is not to consider the intellectual merits of the new proposition. Doing so would require us to occupy an uncomfortable space, a space of cognitive dissonance. It is far easier for us to reject new suppositions in favour of reinforcing our existing beliefs, just as the smoker does when justifying his habit in the face of medical evidence warning of the long-term health effects of smoking cigarettes with a statement such as: "I only smoke after dinner and I try to eat healthy foods." Our human imperative to minimize cognitive dissonance has the net effect of discouraging us from being philosophically minded. It is far easier to believe that we are acting in a moral and just manner. ${ }^{23}$

Certainty of truth, or the presumption and entrenchment of knowledge, is akin to resolving that on any particular matter, we may cease to probe, to question, and to uncover. For Socrates, who most frequently claimed no answers but who had no lack of questions to direct at others' assumptions, the educator's role was to help students bring forward ideas that were true and just, regardless of their prior convictions. Of grave concern was the birthing of ideas that would develop and mature healthily and robustly. Socrates' mother was a midwife in Athens, and the philosopher believed that he practiced a particular midwifery of ideas:

For I have this in common with the midwives: I am sterile in point of wisdom, and the reproach which has often been brought against me, that I question others but make no reply myself about anything, because I have no wisdom in me, is a true reproach; and the reason of it is this: the god compels me to act as midwife, but has never allowed me to bring forth. I am, then, not at all a wise person myself, nor have I any wise invention, the offspring born of my own soul; but those who associate with me, although at first some of them seem very ignorant, yet, as our acquaintance advances, all of them to whom the god is gracious make wonderful progress, not only in their own

Socrates' defense was unsuccessful and he was condemned to death by his fellow citizens; he cautioned them, however, as follows: "For if you put me to death, you will not easily find another, who, to use a rather absurd figure, attaches himself to the city as a gadfly to a horse, which, though large and well bred, is sluggish on account of his size and needs to be aroused by stinging. I think the god fastened me upon the city in some such capacity, and I go about arousing, and urging and reproaching each one of you, constantly alighting upon you everywhere the whole day long.." Plato, Apology (30e-31a).

21 Socrates testified that he was wise because he was aware of his own ignorance; he had learned that he had infinitely more to learn. In relation to others, who claimed to be certain of knowledge that was uncertain, Socrates found that his modest claims concerning matters of understanding constituted wisdom: "I am likely to be wiser than he to this small extent, that I do not think I know what I do not know." Plato, Apology (21d).

22 Socrates avowed to pursue greater truths via an examination of self and others, even unto death. With his life on the line, before a jury of his peers, he avowed: "The unexamined life is not worth living" Plato, Apology (38a).

${ }^{23}$ Carol Tavris and Elliot Aronson, Mistakes Were Made (But Not By Me): Why We Justify Foolish Beliefs, Bad Decisions, and Hurtful Acts (Orlando: Harcourt Inc., 2008). 
opinion, but in that of others as well. And it is clear that they do this, not because they have ever learned anything from me, but because they have found in themselves many fair things and have brought them forth. But the delivery is due to the god and me. ${ }^{24}$

A noteworthy caveat here concerns our responsibility as educationists towards the querying of our own assumptions and our own pedagogical ideas. To presume our own knowledge claims, curricula, policies, or practices are correct, but to systematically prod others' is to cloak hypocrisy in the veil of philosophical mindedness. It is firstly to our own assumptions, presumptions, and actions that we much look inquisitively; to act otherwise is hypocrisy. ${ }^{25}$ Educationists certainly have a responsibility towards their students and colleagues, which concerns the questioning of established beliefs or practices and the promise of potential reform; exploring wisdom and asserting a philosophical position to pursue, even tentatively stated or contextually bound, however, is essential for stakeholders in education. Philosophy can operate as a rudder in a storm at sea, navigating and steering each educationist through the despair, confusion, and delights of teaching and learning. If Socrates is correct in his assertion that we find within ourselves many truths and understandings, then the onus upon us is to seek these doggedly and stubbornly. We are compelled to live philosophically and to make the questions of philosophy the forces that lead us forward in our lives in education.

In a contemporary context, Maxine Greene epitomizes the philosophically minded educator. Tony Johnson and Ronald Reed characterize her pedagogical approach in terms that evoke stark Socratic parallels, explaining how "Greene has never stopped teaching, purposefully shocking her students and colleagues into an awareness of the taken for granted in hopes of enabling them to become more critical and human beings in an uncertain world." 26 In her own words, Greene tries, with her students, to be "wide-awake" and to "resist meaningless along with objectness and cruelty and injustice. Otherwise, why live?" 27 The philosophically minded life, for Greene as much as for Socrates, imbues experiences with meaning and purpose that cast an unexamined life into shade and squalor.

Johnson and Reed note that philosophy offers a view of education extending beyond the classroom, the school building, and even training or preparation for life. Introducing the philosophers Michael Oakeshott and Jane Roland Martin, they explain that for these thinkers:

education is the development of intellectual and moral habits through the give-and-take of the conversation that ultimately gives 'place and character to every human activity and utterance.' Education - the conversation-is the place where one comes to learn what it is to be a person. ${ }^{28}$

Oakeshott indeed characterizes the aims and substance of philosophy of education as habits of mind cultivated via an ongoing conversation with ideas stretching back through time, not the adoption of or adherence to doctrines and schools. He argues that philosophy and education can be akin to an ongoing and active reflection with ideas that resembles a conversation within and amongst ourselves, permitting us as educators to:

acquire the intellectual and moral habits appropriate to conversation. And it is this conversation which, in the end, gives place and character to every human activity and utterance. ${ }^{29}$

\footnotetext{
24 Theaetetus $150 \mathrm{c}-\mathrm{d}$.

25 This point has been commented upon most directly in biblical scripture, where Jesus proclaims: "You hypocrite! First remove the beam from your own eye, and then you will see clearly enough to remove the speck from your brother's eye." Matthew, 7:5, International Standard Version.

26 Tony W. Johnson and Ronald F. Reed, Philosopbical Documents in Education (Boston: Allyn \& Bacon, 2008), 16-17.

${ }_{27}$ William Ayers and Janet L. Miller, eds. A Light in Dark Times: Maxine Greene and the Unfinished Conversation. (New

York: Teachers College Press, 1998), x.

28 Johnson and Reed, Philosophical Documents in Education, 166.

${ }^{29}$ Michael Oakeshott, Rationalism in Politics and Other Essays (London: Methuen, 1962), 199.
} 
Again, philosophy is characterized not as abstract intellectual activity, but as a habit of mind and as a disposition to the world which imbues life in education with meaning.

In Reclaiming a Conversation (1985), Jane Roland Martin also depicts philosophy as a conversation with ideas; she remarks, however, that this conversation has largely excluded women as subjects and as voices. We have noted our concern for drawing all stakeholders in education-all educationists-into a philosophical mindedness project. In this regard, Martin's discussion of the historical marginalization of females from philosophy merits attention. Drawing from sociological research initiated in the 1970s, Martin reveals that gender bias across intellectual disciplines marginalizes females in at least three ways: "They exclude women from their subject matter, distort the female according to the male image of her, and deny value to characteristics the society considers feminine." 30 Correctly, she argues that Plato's and Rousseau's discussion of education for women is often excluded in discussion of the philosophers' pedagogical ideas, and the writing of female philosophers of education, including Mary Wollstonecraft, Maria Montessori, Catharine Beecher, and Charlotte Perkins Gilman garner secondary consideration. In reconstructing a vision for philosophy of education as an intellectual habit, which all educationists should rightly practice, we caution that the historical gender inequalities cannot persist; particularly when we consider that the majority of educationists working as elementary school teachers are female. ${ }^{31}$ Martin's concerns, thus, beg that we pay heed:

Men and women need to claim the best possible education for themselves and their sons and daughters. All must listen to and participate in conversation about the ideals governing the education of both sexes. Only then will we understand that the education most of us receive today is too narrow. Only then can we begin to construct theories of education that give the reproductive as well as the productive processes of society their due, and only then can we press our questions of 'value, virtue, veracity, and validity' in relation to the whole range of educational concerns. ${ }^{32}$

Each educationist as stakeholder in education-parent, teacher, administrator, and student—is called upon to engage in a conversation about ideas and ideals. Each educationist is called to be philosophically minded.

\section{Philosophical Mindedness as an Ethic}

We may not ever achieve wisdom, but we must strive for it ceaselessly to shape the way that we live and act in the world. Hadot argued that philosophy conceived of as it was in classical Athens and Rome requires perpetual exercise and discipline:

With the possible exception of the Epicurean school, wisdom was conceived as an ideal after which one strives without the hope of ever attaining it. Under normal circumstances, the only state accessible to man [sic] is philo sophia, the love of, or progress toward, wisdom. ${ }^{33}$

Philosophical mindedness, then, is not a matter of acquiring a skill or strategy, which, once learned, transforms our lifestyle and behaviour. ${ }^{34}$ Philosophical mindedness is an ethic, which is necessarily

\footnotetext{
30 Jane Roland Martin, Reclaiming a Conversation: The Ideal of the Educated Woman (New Haven, CT: Yale University Press, 1985), 1.

${ }^{31}$ For instance, in 2006 approximately $84 \%$ of Canadian primary and preschool teachers were women. See Martin Turcotte, "Women and Education" in Women in Canada: A Gender-based Statistical Report. (Statistics Canada Catalogue no. 89-503-X. Ottawa, Ontario, 2011).

32 Turcotte, "Women and Education", 6.

${ }^{33}$ Hadot, Philosophy as a Way of Life, 103.
} 
personal and thoughtful, and which must be experienced and embodied, not merely preached. ${ }^{35}$ At the peril of reducing this ethic to a list of principles, Sears and Parsons (1991) outline attitudes that underlie the ethic of critical thinking. These include an attitude that: knowledge is not fixed as it necessarily subject to reexamination; there are no questions that need not be asked; alternative worldviews and ways of knowing to our own exist, meritorious of consideration; ambiguity is tolerable; we must be skeptical; and, human life is complex. ${ }^{36}$ Philosophical mindedness as a habit of mind and as an aim, similarly, can best be understood as the embodiment and practice of attitudes. As a culture, philosophically minded educationists see, interpret, engage with, and act upon the world as if critical thinking were an ethic. We cannot consider education independently of ethics, and when the aims of educators concern the implementation of systems or models, they risk making of educators what Ted Aoki refers to as "a person reduced to a technical practitioner." 37

John Dewey, notable forerunner to the yoking of experience and activity in educational philosophy, terms the habits outlined above "reflective experience," which involve:

- Perplexity, confusion, doubt, because one is implicated in an incomplete situation whose full character is not yet determined;

- A conjectural anticipation-a tentative interpretation of the given elements, attributing to them a tendency to effect certain consequences;

- A careful survey (examination, inspection, exploration, analysis) of all attainable considerations which will define and clarify the problem at hand;

- A consequent elaboration of the tentative hypothesis to make it more precise and more consistent, squaring it with a wider range of facts;

- Taking one's stand upon the projected hypothesis as a plan of action which is applied to the existing state of affairs: doing something overtly to bring about the anticipated result and thereby testing the hypothesis. ${ }^{38}$

Dewey offers a method for being philosophically minded, which attempts to distill the intellectual habits outlined above; any such method, when taken as a series of steps to be adhered to rigidly is at peril of forsaking the spirit for the letter of law. Dewey reminds us of a point noted earlier; the philosophically minded attitude is a difficult disposition to hold, for doubt and perplexity require living with the tensions of cognitive dissonance. Living philosophically as educationists requires of us more than doubt, suspicion, and an interrogative outlook. It is, further, a call to action involving the assumption of positions or ideals, the testing of these in accordance with experience, and the awareness of the complex indeterminacy of life.

\footnotetext{
34 Philo of Alexandria enumerated exercises, which together constitute a Stoico-Platonic catalogue of what we are calling here the ethic of philosophical mindedness. These include: a) research (zeteisis), thoughtfulness (skepsis), reading (anagnosis), listening (akroasis), attention (prosoche), self-mastery (enkrateia), and meditation (meletai). Philo Judaeus, Who is the Heir of Divine Things, 253, cited in Hadot, Philosophy as a W ay of Life, 84.

35 Alan Sears and Jim Parsons, "Towards Critical Thinking as an Ethic," Theory and Research in Social Education, XIX, no. 11 (1991): 45-68. Alan Sears and Jim Parsons, writing about the aim of fostering critical thinking in social studies education, argue that critical thinking is an ethic rather than a strategy that can be learned or imposed. Their use of the term ethic is founded on their belief that critical thinking requires an ongoing commitment on the part of the learner. We argue that the same is necessary for philosophical mindedness.

${ }^{36}$ Sears and Parsons, "Towards Critical Thinking as an Ethic," 55-65.

37 Ted Aoki, "Layered Understandings of Curriculum and Pedagogy: Challenges to Curriculum Developers" (paper presented at The Alberta Teachers Association: Symposium Empowering Teachers as Curriculum Developers, Edmonton, AB, 1989), 18. Cited in Sears \& Parsons, "Towards Critical Thinking as an Ethic," 54. ${ }^{38}$ John Dewey, Democracy and Education (New York, NY: Macmillan, 1916), 150.
} 


\section{Conclusions}

The dismal failures of reform in education are well documented and the educational research literature is full of cautionary tales of aligning exclusively with particular theoretical camps at the expense of other ideas. Similarly, the literature on professional development brings to mind images of teachers stubbornly "resisting" change in their classrooms, much to the chagrin of reformers and in-service teacher educators. Seymour Sarason reminds us that we all come to problems of education with inherently insider perspectives because most adults have significant experiences in organized school systems. ${ }^{39}$ It is little wonder that education researchers, teachers, parents, government officials, and even students tend to approach problems of education reform and change with viewpoints and knowledge that are deeply grounded in particular points of view - that of the insider — at the expense of other considerations.

In this essay we argued that those who would concern themselves with educationeducationists-would do well to approach problems of education with an orientation toward philosophical mindedness. Being a philosophically minded educationist means occupying a radical middle between opposing viewpoints and thinking critically, in action, about educational experiences. Far from stereotypical notions linking philosophy to abstract ideals of the ivory tower, we argue that being an educationist and taking that responsibility seriously means being a frontline classical philosopher, one who loves wisdom, and who is willing to facilitate the birth of ideas. Perhaps by embracing an ethic of ambiguity, a willingness to question presuppositions, and a disposition of pragmatism, educationists can move more fully toward the notion of philosophical mindedness.

\section{References}

Aoki, Ted. "Layered Understandings of Curriculum and Pedagogy: Challenges to Curriculum Developers." Presentation at The Alberta Teachers' Association: Symposium Empowering Teachers as Curriculum Developers. Edmonton, AB, 1989.

Ayers, William and Janet L. Miller, eds. A Light in Dark Times: Maxine Greene and the Unfinished Conversation. New York: Teachers College Press, 1998.

Bruno-Jofré, Rosa and Karen Steiner. "Fostering Educative Experiences in Virtual High School History." Encounters/Encuentros/Rencontres on Education 8 (2007): 69-82.

Bullock, Shawn Michael, and Theodore Christou. "Exploring the Radical Middle Between Theory and Practice: A Collaborative Self-study of Beginning Teacher Educators." Studying Teacher Education: A Journal of Self-study of Teacher Education Practice 5, no. 1 (2009): 75-88.

Darling-Hammond, Linda and Joan Baratz-Snowden, eds. A Good Teacher in Every Classroom: Preparing the Highly Qualified Teachers our Children Deserve. San Francisco: Jossey-Bass, 2005.

Dewey, John. "Body and Mind." In The Later Works of John Dewey, 1925-1953. Volume 3: 1927-1928. Carbondale, IL: Southern Illinois University Press, 2008.

-----. Democracy and Education. New York: Macmillan, 1916.

-----. "Syllabus: The Pragmatic Movement of Contemporary Thought." In The Middle Works of John Dewey, 1899-1924. Volume 4: 1907-1909. Carbondale, IL: Southern Illinois University Press, 2008.

Granatstein, Jack L. Who Killed Canadian History? Toronto: HarperCollins, 1998.

Hadot, Pierre. Philosophy as a Way of Life. Cambridge, MA: Blackwell Publishers Inc., 1995.

\footnotetext{
${ }^{39}$ Seymour B. Sarason, Revisiting "The Culture of the School and the Problem of Change" (New York: Teachers College Press, 1996).
} 
-----. What is Ancient Philosophy? Cambridge, MA: The Belknap Press, 2002.

Hirsch, Eric D. Jr. Cultural Literacy: What Every American Needs to Know. New York: Random House, Inc., 1988.

Johnson, Tony W. and Ronald F. Reed. Philosophical Documents in Education. Boston: Allyn and Bacon, 2008.

Laertius, Diogenes. Lives of the Philosophers. Translated by C. D. Yonge. London: Bohn's Classical Library, 1895. Book 7, Section 39. http://www.attalus.org/old/diogenes7b.html.

McLaughlin, Andrew C., Herbert B. Adams, George L. Fox, Albert Bushnell Hart, Charles H. Haskins, Lucy M. Salmon, and H. Morse Stephens. "The Study of History in Schools: A Report to the American Historical Association by the Committee of Seven, 1898." American Historical Association, 1898. http://www.historians.org/pubs/archives/CommitteeofSeven/index.cfm.

Oakeshott, Michael. Rationalism in Politics and Other Essays. London: Methuen, 1962.

Osborne, Ken. "Book Reviews- Knowing, teaching and learning history. Edited by Peter Stearns, Peter Seixas, and Sam Weinburg. New York: New York University Press, 2000, and 'L'histoire à l' école: Matière à penser,' Robert Martineau. Paris and Montreal: L'Harmattan, 1999," The Canadian Historical Review 82, no. 3 (2001): 548-604.

Plato. Plato in Twelve Volumes, Vol. 1. Translated by Harold North Fowler. Cambridge, MA: Harvard University Press, 1966.

Roland Martin, Jane. Reclaiming a Conversation: The Ideal of the Educated Woman. New Haven, CT: Yale University Press, 1985.

Sarason, Seymour B. Revisiting "The Culture of the School and the Problem of Change." New York: Teachers College Press, 1996.

Sears, Alan and Jim Parsons. "Towards Critical Thinking as an Ethic." Theory and Research in Social Education, XIX, no. 11 (1991): 45-68.

Tarrant, Harold. Introduction to Plato: The Last Days of Socrates. London, UK: Penguin, 1993.

Tavris, Carol \& Elliot Aronson. Mistakes Were Made (But Not By Me): Why We Justify Foolish Beliefs, Bad Decisions, and Hurtful Acts. Orlando: Harcourt Inc., 2008.

Turcotte, Martin. "Women and Education." In Women in Canada: A Gender-based Statistical Report. Statistics Canada Catalogue no. 89-503-X. Ottawa, Ontario, 2011.

Wardy, Robert. Doing Greek Philosophy. London and New York: Routledge, 2006.

\section{About the Authors}

Theodore Christou is Assistant Professor at Queen's University in the Faculty of Education. He teaches social studies, history of education, and philosophy of education. Theodore is a published poet and an advocate for the humanities in teacher education. His email is tmc@unb.ca and his professional webpage can be found at http://www.theodorechristou.ca

Shawn Michael Bullock is Assistant Professor at the University of Ontario Institute of Technology. He teaches physics methods in the teacher education program and adult education courses in the graduate program. Shawn is particularly interested in how problems of learning science and problems of learning to teach science interact with each other. His email is shawn.bullock@uoit.ca and he maintains an active online presence at http://shawnbullock.ca 